\title{
MOBILE LOYALTY APPLICATION DEVELOPMENT BASED ON ANDROID
}

\author{
Angela Irina ${ }^{1}$; Megawati $^{2}$; Abednego ${ }^{3}$; Natalia Chandra ${ }^{4}$; \\ Irma Kartika Wairooy ${ }^{5}$; Alvina Aulia ${ }^{6}$ \\ 1,2,3,4,5,6 Mobile Application and Technology and Computer Science Department, \\ School of Computer Science, Bina Nusantara University \\ Jln. K.H. Syahdan No. 9 Palmerah, Jakarta Barat, 11480 \\ nnchandra@binus.ac.id; ${ }^{5}$ iwairooy@binus.edu; ${ }^{6}$ aaulia@binus.edu
}

\begin{abstract}
The research objective is to develop an application that allows users to participate in a loyalty program and facilitate Smartphone enterprise (Merchant) in access, sale and observation of customer transactions through mobile applications. Design method used is object-based design that includes a UML of use case diagrams, use case narrative, class diagram, sequence diagrams and activity diagrams. Results achieved in the form of mobile applications that are able to facilitate customer in managing loyalty cards as well as to increase customer loyalty. This application features, such as add points, redeem, news, transaction history, and message that can facilitate customer in managing customer loyalty card. The conclusion of this design is that the application of E Points can enable customers to manage a loyalty card in Smartphone, add points, redeem rewards, obtain the latest promotional information through news features, and view transaction history.
\end{abstract}

Keywords: android, loyalty, mobile

\section{INTRODUCTION}

Technological development in telecommunications grows very rapidly. At first, cell phone only limited to voice communication and data transmission communication, such as text, images, video, and mobile devices. Until now, mobile phones evolve into Smartphone. The differences between a Smartphone and a cell phone apart from having the basic functions of mobile phones, Smartphones can also act like a personal assistant (Fitchard, 2005). Mobile phone can be called as Smartphone if it uses the operating system. Currently the most common operating system used is Android. Android has significantly developed the most. In 2011, Android users were only about 100 million people, in 2012 Android users reached approximately 400 million users. Google also explained that in a day alone, there are approximately 1 (one) million new users of Android-based devices (Merdeka, 2012).

A key competitive advantage in a competitive situation is the company's ability to increase customer loyalty. Customer loyalty becomes a key to success and the company's competitive advantage, not only short term but also long-term (Kotler, 2012). Many companies seek to increase customer loyalty to trigger repeat purchases (repeat order) in various ways, such as collecting stamps or points, providing discounts, and others. In general, this loyalty program is provided in the form of cards loyalty. Advancement mobile technology can facilitate customers in store loyalty cards practically. With the E Points, customers do not need to carry a lot of cards, all cards will be replaced with Smartphone to provide flexibility for customers and prevent the possibility of lost or damaged cards. This application will feature promotions and news that can enable customers to know the latest news and promotions from Merchants without having to visit a store to see the ad campaign. 
Verma (2013) argued that the concept of loyalty-based mobile applications provides many benefits for customers and the company (Merchant). Besides as a marketing strategy, the application enables remote employees to use mobile devices, such as Smartphones and tablets to access, updates, and interacts with the data of customers at any time and wherever they are. Another feature that provide application is a mobile-based loyalty management, self-rewards point status, media advertising and promotion, confirmation of payment via SMS, and mobile coupon.

Problems found in this study are: does customer now find it easy to follow the loyalty program? Do customer loyalty programs can easily get the latest news and information from the Merchant? Does the Merchant can easily access, provide promotional programs and view customer transactions?

\section{METHODS}

The method used in this study is divided into two, namely method of data collection and software development. Method of data collection is divided into four stages, namely: (1) Questionnaire Analysis: this stage aims to know for sure who the target users of the application made along with the needs of the target users, so that later the application is made to the right target. (2) Literature Study: searching for references related to the preparation of the research. Searches are done through the internet, theses and other literature relating to the application to be made. (3) Application Analysis: this phase is done by analyzing and comparing the features contained in existing applications. This is done to discover the advantages and disadvantages of the previous application. (4) Interview: interviews are conducted to evaluate the application that has been made. Guest speaker in this interview are those who have long engaged in the field of computer science or any other field that is quite related to the application.

While the software development method used is Scrum. The stages of Scrum method are as follows (Pressman, 2010): (1) Backlog: at this stage, the backlog will be determined a list of project requirements or features that are developed. Here is an application backlog E Points. (2) Sprint: at this stage, the backlog has been described to break down into more specific to do list. Once it is done in accordance with the application execution, to do list has been created. This stage is repeated until the applications are developed according to the needs. (3) Scrum Meeting: during the sprint stages, a brief meeting is conducted between Scrum team members to discuss development progress and problems encountered during the development of applications. (4) Demos: at this stage, the application is tested by the parties relating to the development of applications to ensure the application complies with the requirements. Then it will be evaluated and documented.

As in the design diagram using design methods of Unified Modeling Language (UML), using diagrams like Use Case Diagrams, Use Case Narrative, Class Diagram, Activity Diagram and Sequence Diagram (Whitten and Bentley, 2007), as seen in Figure 1-17 are: 


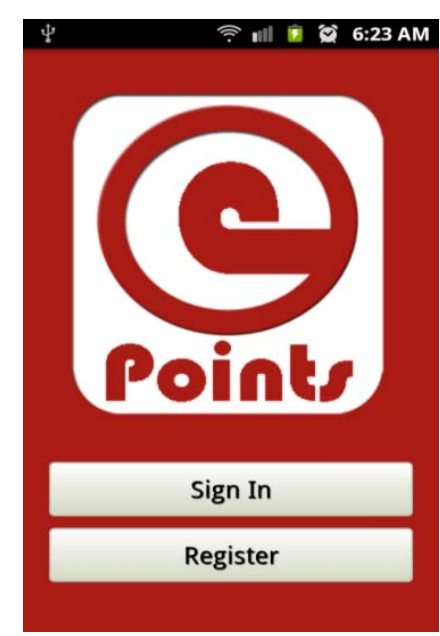

Figure 1 The Display of Home

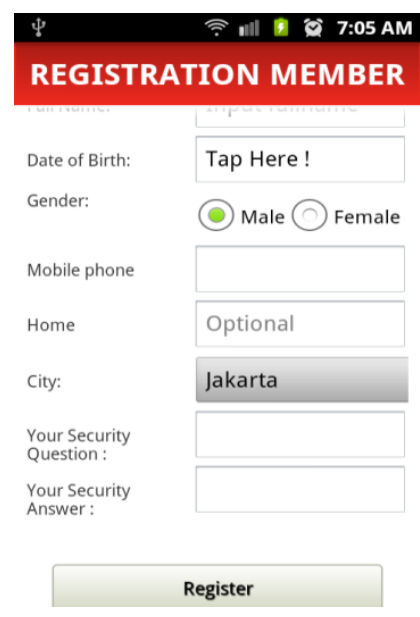

Figure 3 The Display of Registration (2)

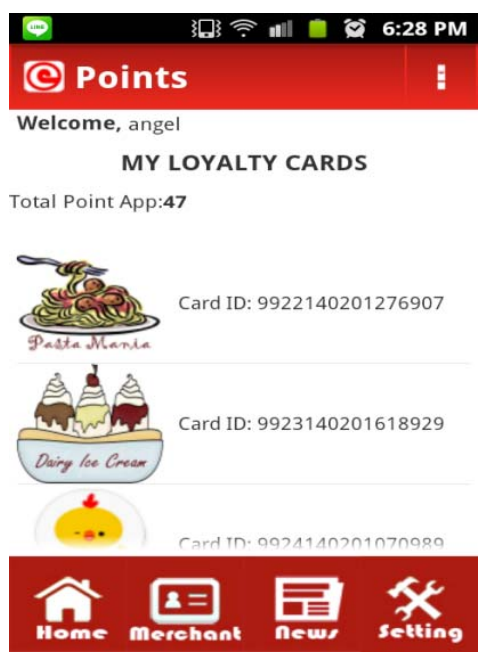

Figure 5 The Display of Menu Home

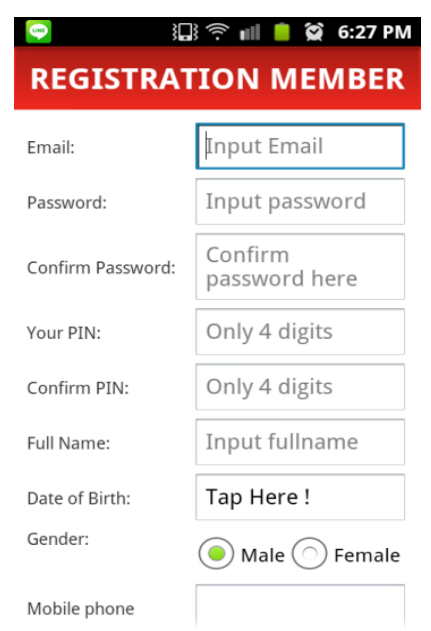

Figure 2 The Display of Registration (1)

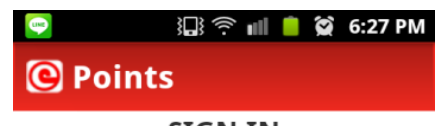

\section{SIGN IN}
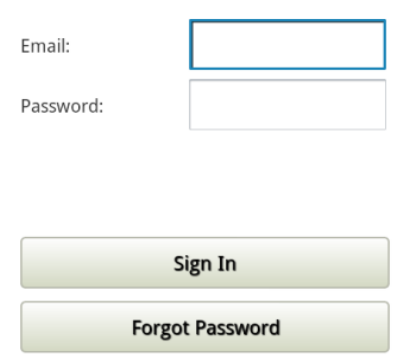

Figure 4 The Display of Sign In
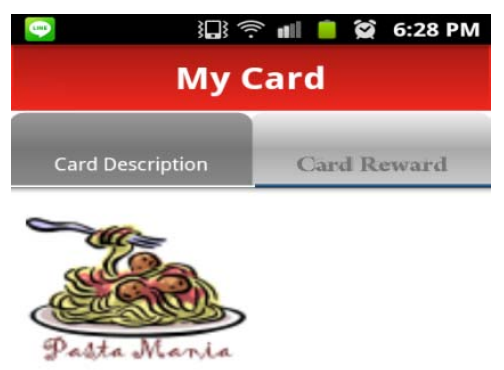

Pasta Mania

Point

200

Join Date

2014-02-02 13:37:22

Description : Find your favorite pasta here!

Figure 6 The Display of My Card Description 

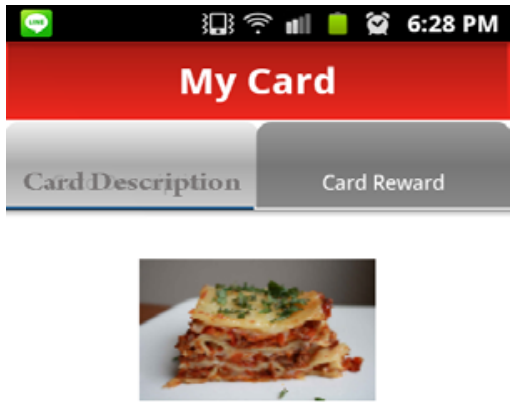

\section{Lasagna Bolognese}

Startdate : 2014-02-04 10:00:00

Valid Until $\quad$ : 2014-09-30 22:00:00

Point Redeem : 500

Figure 7 The Display of My Card Reward

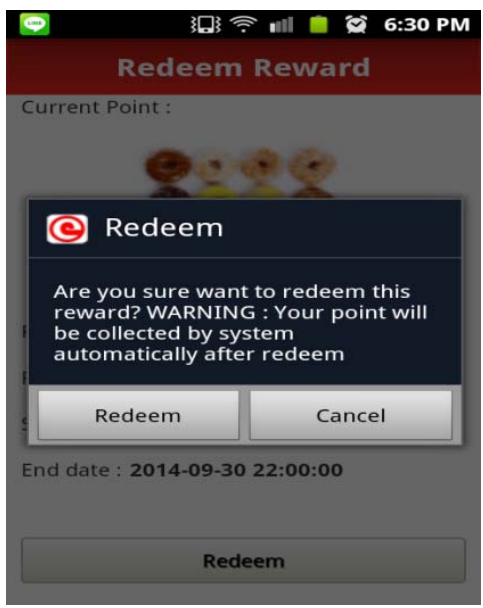

Figure 9 The Display of Confirm Redeem
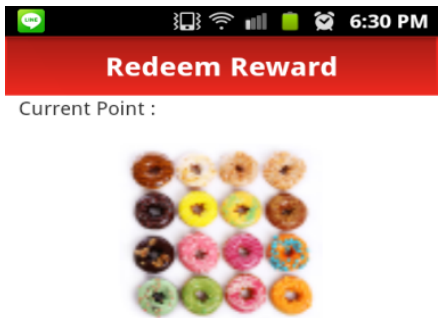

Reward name : A dozen donuts by Krispy

Point redeem : 75

Start date : 2014-02-06 09:00:00

End date : 2014-09-30 22:00:00

Redeem

Figure 11 The Display of Redeem Reward Application

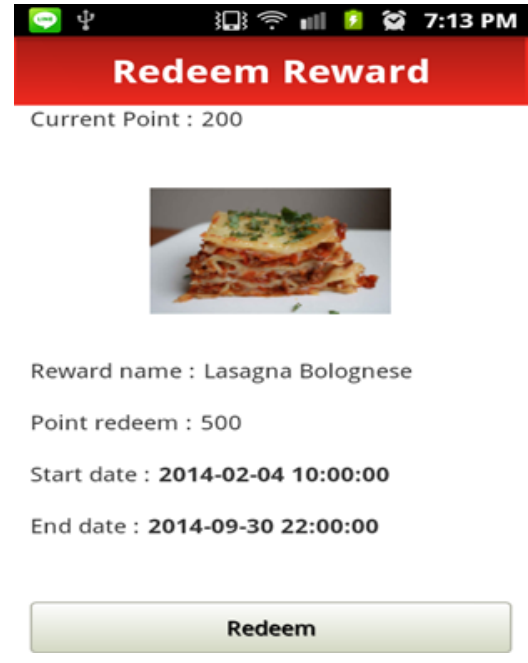

Figure 8 The Display of Redeem Reward Merchant

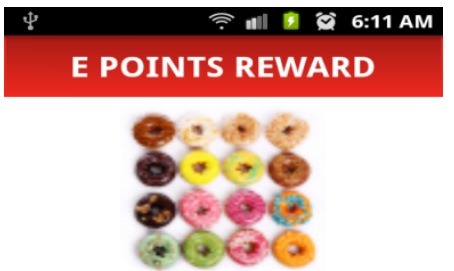

A dozen donuts by Krispy Donuts

Point Redeem: 75

Startdate: 2014-02-06 09:00:00

Valid Until: 2014-09-30 22:00:00

재잔?

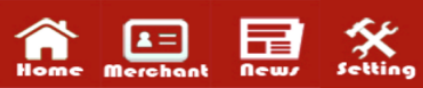

Figure 10 The Display of E Points Reward

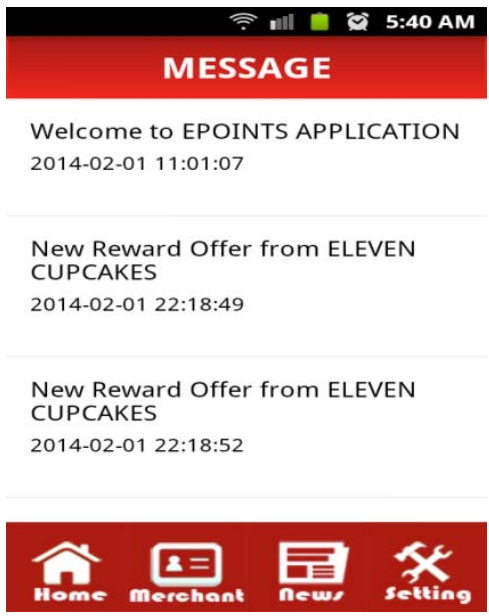

Figure 12 The Display of Message (1) 


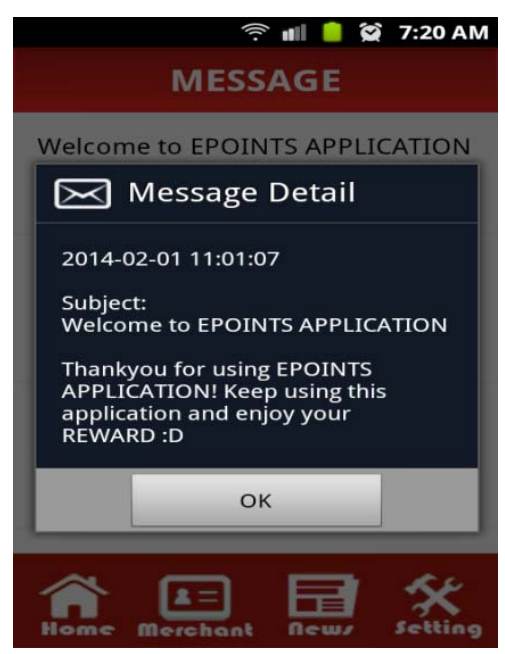

Figure 13 The Display of Message (2)

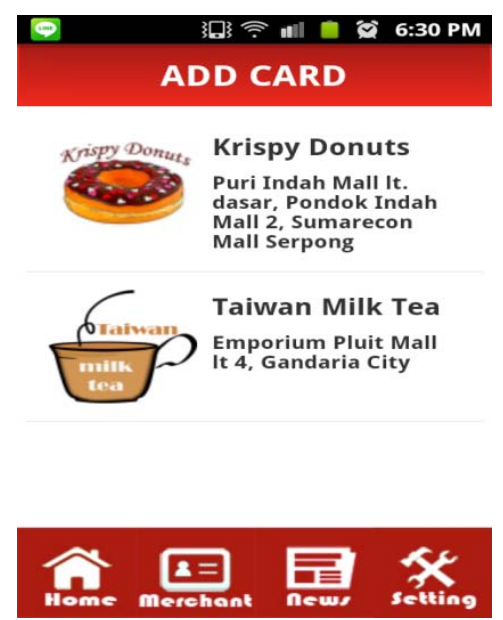

Figure 15 The Display of Merchant

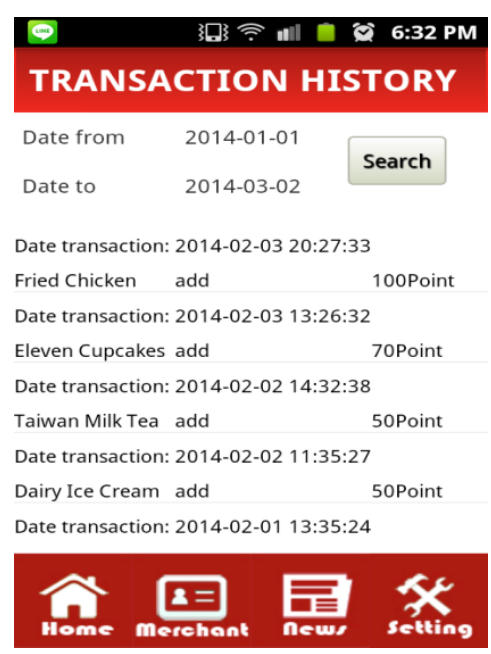

Figure 14 The Display of History Transaction

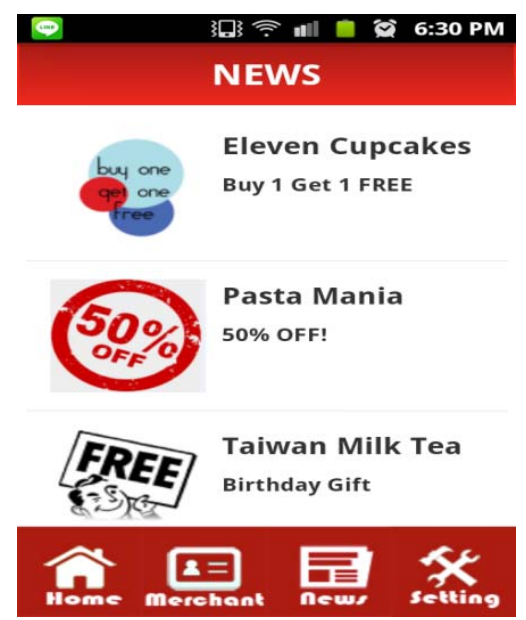

Figure 16 The Display of News

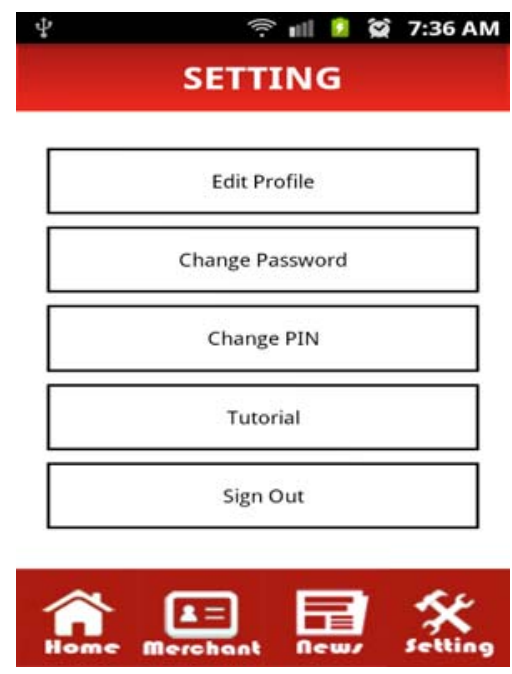

Figure 17 The Display of Setting 
The second process is research evaluation. This evaluation phase is divided into four stages, namely: evaluation by application of the result of questionnaire, application evaluation of the 10 principles of mobile interface design, application evaluation based on 5 human factors measurement, the application evaluation based on interview.

\section{RESULTS AND DISCUSSIONS}

Evaluation by Application of the Result of Questionnaire can be seen in Figure 18 - 22:

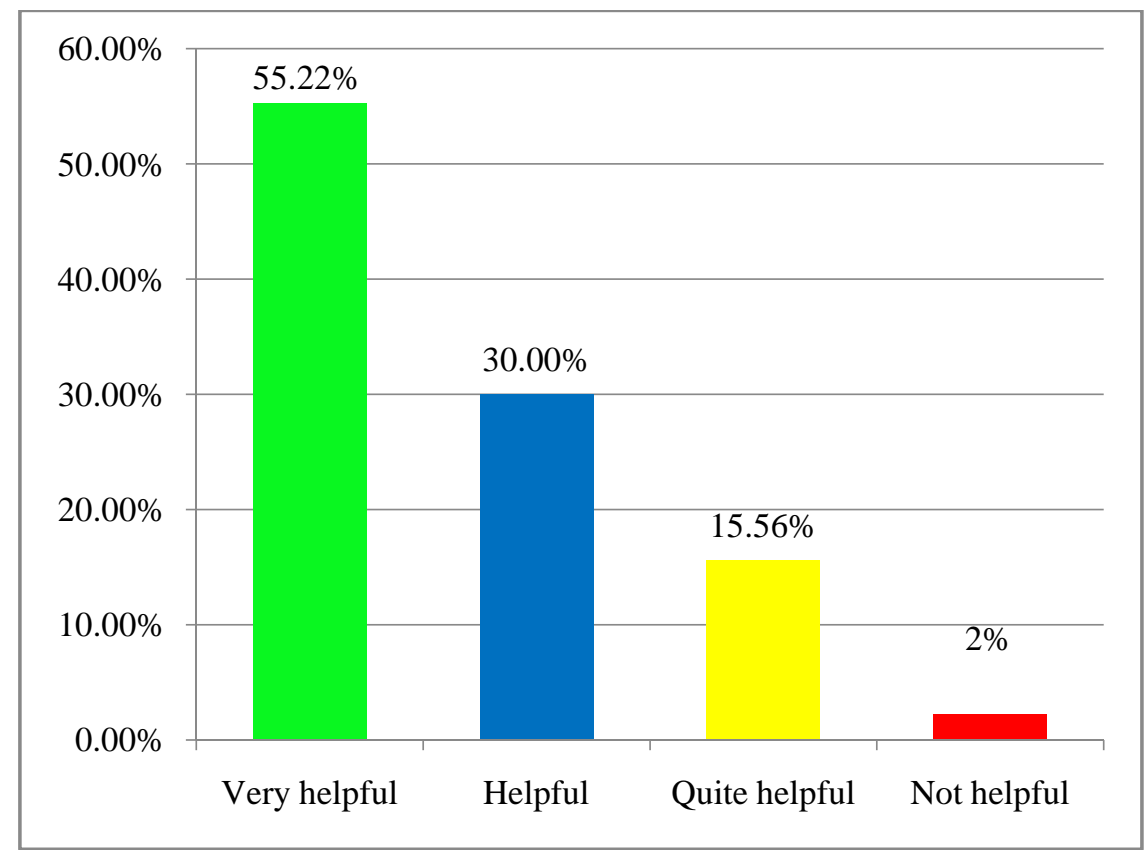

Figure 18 Histogram of the Result for Evaluation Question Number 1:

Does E Points can help you to manage loyalty cards?

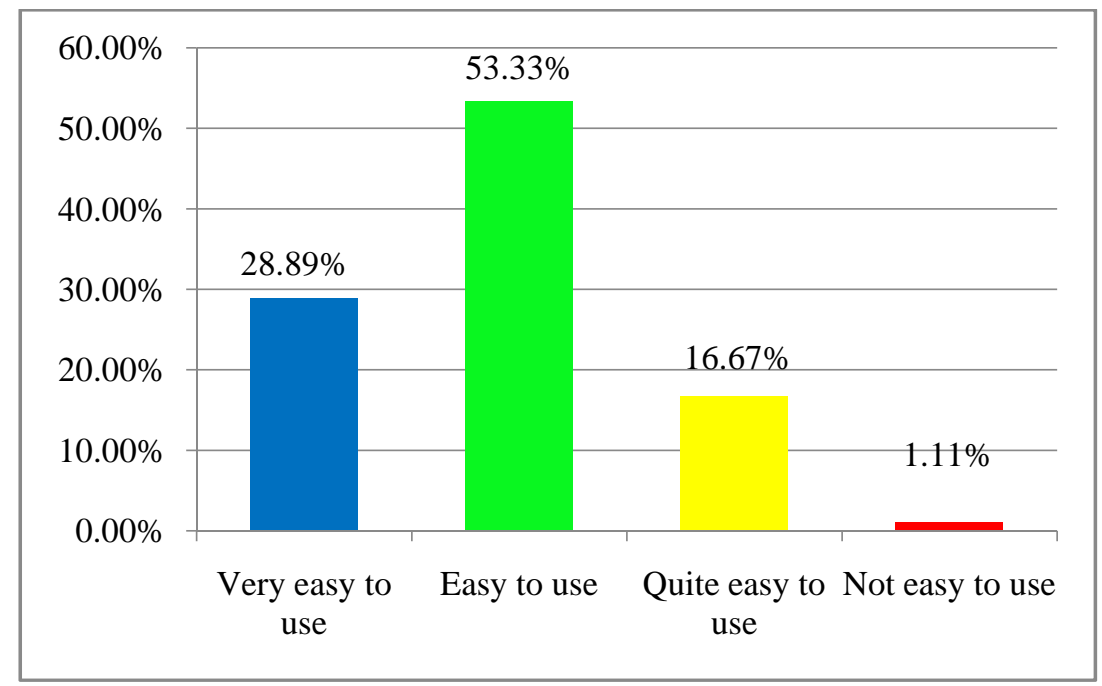

Figure 19 Histogram of the Result for Evaluation Question Number 2: Does E Points easy to use? 


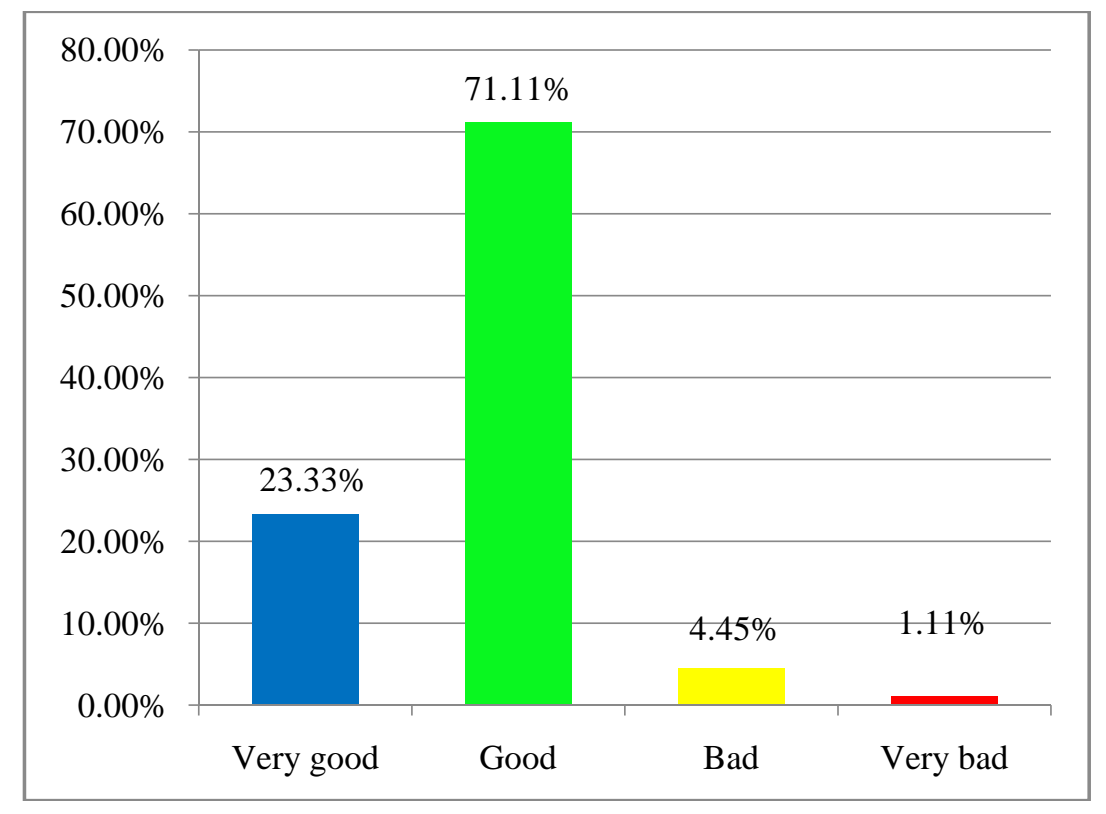

Figure 20 Histogram of the Result for Evaluation Question Number 3: How Does E Points User Interface Design?

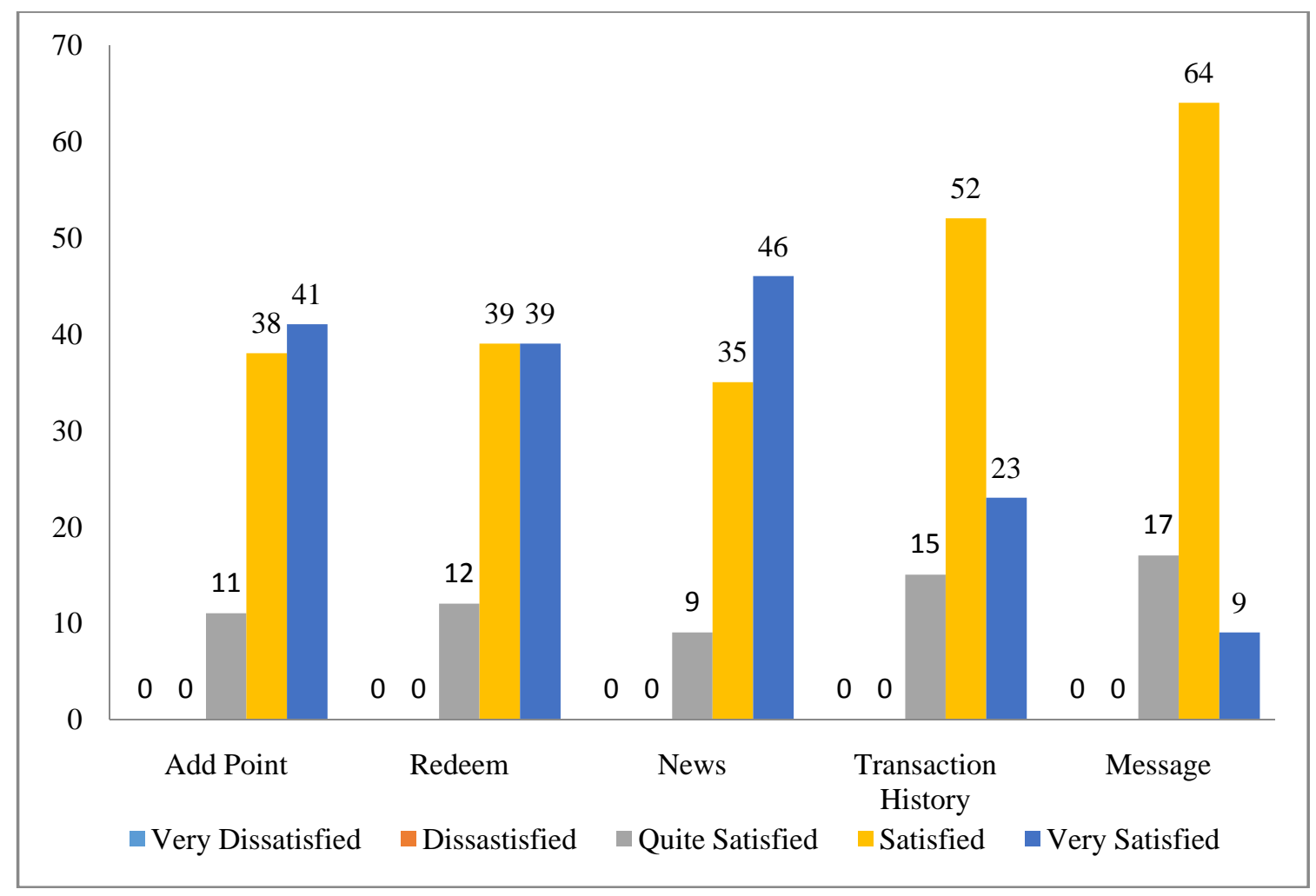

Figure 21 Histogram of the Result for Evaluation Question Number 4: Give a scale scoring 1 - 5 of E Points features! (1) = Very Dissatisfied (2) = Dissatisfied, (3) = Quite Satisfied, (4) = Satisfied, (5) = Very Satisfied 


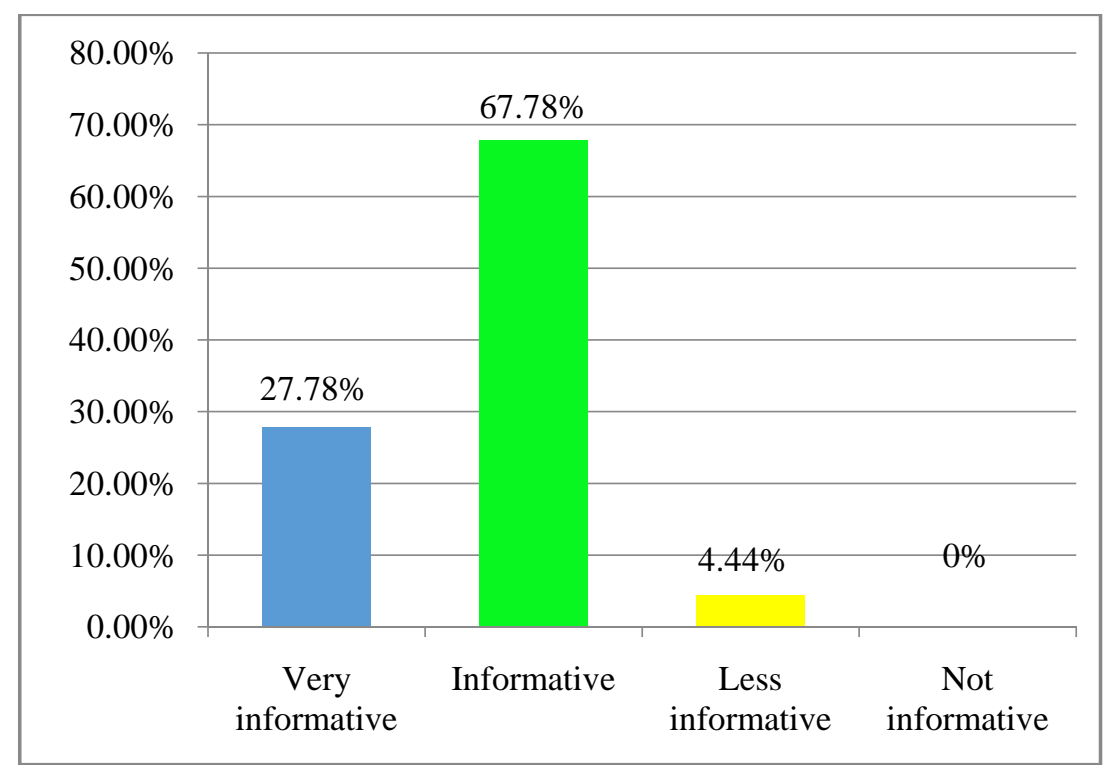

Figure 22 Histogram of the Result for Evaluation Question Number 5:

is the content of this information informative? (e.g. news content, transaction history, etc.)

The next question within the questionnaire is: what are your suggestions for the application $\mathrm{E}$ Points for future development? Based on the results of the questionnaire, it is suggested for $\mathrm{E}$ Points to be developed with a multi-platform system, not only for the Android platform, but also iOS and Blackberry. It is advisable to use NFC or scan barcodes to facilitate the transaction. In addition, the Merchant list displayed in categories and applications to connect with social media.

\section{Application Evaluation of the 10 Principles of Mobile Interface Design}

Here are the results of the evaluation of E Points based on 10 principles of Mobile Interface Design: (1) Mobile Mindset: E Points application has an interface design that is not excessive and there is a label on the main menu so it would not making user difficult to know the function of its menu. (2) Mobile Contexts: E Points applications developed in accordance with the wishes of the user, where the user can manage a loyalty card in a Smartphone. In addition, the customer also gets the latest news and promotional information from Merchant. (3) Global Guidelines: E Points application provides confirmation during the sign in process, thus the customers know the process is running. (4) Navigation Models: E Points application has a common navigation such as tab bar and menu bar. (5) User Input: customer can provide input easily with keyboard that has been provided. (6) Gestures: customer can easily control the page with numerous contents with scroll gesture. (7) Orientation: Portrait is the orientation that is used in E Points application. (8) Communications: E Points application provides feedback to the customer when performing an action. When the customer does not fill the old password, the new password and confirm the password on the Change Password page, the application will give you an error message. (9) Launching: When the customer has signed out, the application will display the home page. (10) First Impressions: E Points application icon is the letter "e" which is designed as the first letter of the name of the application.

\section{Application Evaluation Based on 5 Human Factors Measurement}

According to Shneiderman (2010), application evaluation is based on five Human Factors Measurement. First, time to learn: based on the results of the questionnaire on question number two, the application E Points are easy to use. Therefore, it can be concluded that the application of E Points 
easy to understand so it does not take a long time to learn the functions that exist in the application. Second, Speed of Performance: based on the results of the questionnaire on the question number four, most respondents said that application features E Points already well underway. Features that are already running well include speed performance. Third, Error: Based on the results of the questionnaire on question number two, respondents said that application E Points are easy to use, thus reducing the level of user errors in using the application.

Fourth, Memory: the display screen on the application E Points made simple so easily understood by users. This is supported by the statement of the respondent on the questionnaire number three and two, that the application display easy to understand and designed well so easier for users to remember how to use the application E Points. Fifth, Subjective Satisfaction: based on the results of the questionnaire, respondents said that $\mathrm{E}$ Points is very helpful in managing loyalty card. This suggests that the beneficial applications built for users, in addition to the applications that are easy to use, good interface design and informative content can also provide subjective satisfaction of the users.

\section{The Application Evaluation Based On Interview}

Evaluation of the interview to the Merchant has been done with five respondents who already have a business. The following are the questions given to respondents. First, does E Points Application can help you to get a loyalty from customer? Customer loyalty cannot be viewed from a single factor such as the use of mobile loyalty system. There are several things that can affect customer loyalty. However, according to the respondents of this application is an excellent tool to facilitate loyalty program, not only for customers but also for the respondents. If the various existing features are supported with maximum promotion of the developer, respondents felt that this application will be very helpful to gain customer loyalty.

Second, does report feature help you to analyze customer's transaction? Report feature is very helpful in analyzing the business briefly and quickly. This is because the report feature can be used anywhere with the real time transaction data. Third, do both news feature and reward feature made you easy to promote you product? News and reward features greatly facilitate respondents in promoting a product or brand.

Fourth, does E Points Application easy to use? E Points Application is easy to use and easy to learn. Fifth, what features are most helpful in gaining customer loyalty? News and reward features greatly help attract customers because the respondents can easily publish promotions. Add points and redeem points features in the Customer applications also facilitate customer loyalty program. It can be concluded that these features can help increase customer loyalty.

Sixth, do you interest to use this application? Yes, all of the respondents are interested in using these applications to attract more customers. But Merchant also expects this application could be promoted so well that attract more customers to the respondent. Seventh, what is your advice on E Points Application for further development? E Points for further development should be made the design look more attractive again.

\section{CONCLUSIONS}

The result of mobile loyalty development that has been done is the application called E Points. Based on the E Points application development that has been done, it can be concluded that: (1) mobile loyalty application makes it easy for customer to follow a loyalty program without having to 
carry a conventional card. (2) Mobile loyalty application makes it easy for customer to get information about promotions and the latest news from the Merchant. (3) Mobile loyalty application makes it easy for customer to view the transaction history for the desired time span. (4) Mobile loyalty application makes it easy for customer to get special rewards from Merchant. (5) Mobile loyalty application can be a means for companies to increase sales and customer loyalty. (6) Merchant facilitates mobile loyalty application in viewing and analyzing customer transactions during a certain time frame. (7) Merchant facilitates mobile loyalty application in promoting the products and the latest news through mobile applications.

From the conclusions that have been obtained, the following suggestions may be considered for further application development: (1) Merchant cooperating list grouped by the category of Merchant. (2) E Points application can be developed for multiplatform, not only for the Android platform, but also for iOS, Blackberry, and others. (3) Applications are associated with social media. (4) It is advisable to use the barcodes to streamline Merchant business processes.

\section{REFERENCES}

Fitchard, K. (2005). A Smartphone for the Masses. Communication-Telephone and Telegraph, 22(4). 19

Kotler, P., \& Keller, K. L. (2012). Marketing Management (14 ${ }^{\text {th }}$ ed.). New Jersey: Prentice Hall.

Merdeka. (2012). Pengguna Android di Tahun 2012 Meningkat 4x Lipat. Retrieved on November 29, 2013 from http://www.merdeka.com/teknologi/pengguna-android-di-tahun-2012-meningkat4x-lipat.html.

Pressman R. S. (2010). Software Engineering: A Practitioner's Approach ( $7^{\text {th }}$ ed.). New York: McGraw-Hill.

Shneiderman, B., \& Plaisant, C. (2010). Designing the User Interface: Strategies for Effective HumanComputer Interaction ( $5^{\text {th }}$ ed.). USA: Addison-Wesley.

Verma, D. (2013). Managing Customer Relationship through Mobile CRM in Organized Retail Outlets. International Journal of Engineering Trends and Technology (IJETT). 4(5). 16981699.

Whitten, J. L., \& Bentley, L. D. (2007). Systems Analysis \& Design Methods (7 $7^{\text {th }}$ ed.). New York: McGraw-Hill. 